\title{
Partitioning of production and respiration among size groups of organisms in an intertidal benthic community
}

\author{
P. Schwinghamer, B. Hargrave, D. Peer \& C. M. Hawkins* \\ Department of Fisheries and Oceans, Marine Ecology Laboratory, Bedford Institute of Oceanography, P.O. Box 1006, \\ Dartmouth, Nova Scotia B2Y 4A2, Canada
}

\begin{abstract}
Published data on production of natural populations of benthic organisms were used to derive allometric equations relating annual production per unit biomass ( $\mathrm{P}: \mathrm{B}$ ratio) to mean individual body mass (time and biomass weighted) in the population on which production was measured. Separate equations were derived for meiofauna and macrofauna. Since no published data on production and size-structure in natural bacterial populations were found, P:B ratios for bacteria were calculated by extrapolation from an all-inclusive regression. In situ respiration was then calculated from production assuming the two to be approximately equal over an annual cycle for bacteria and benthic microalgae, and using an empirical relation between annual respiration and production in marine benthic animals for meiofauna and macrofauna. Monthly observations of benthic biomass spectra at Pecks Cove, an intertidal site in the upper Bay of Fundy, were used to estimate production and respiration in bacteria, microalgae, meiofauna, and macrofauna from the allometric equations. These estimates compared well with measured production for Corophium volutator and Macoma balthica, the 2 dominant macrofaunal species, and with gross primary production by benthic microalgae, but not with total community respiration as measured by sediment oxygen consumption. Calculated values for production by bacteria were of an expected magnitude if between 1 and $10 \%$ of the total biomass was assumed to be active. The contribution of meiofauna and macrofauna to total community production ( 8 to $19 \%$, depending on the assumption for bacterial activity) was disproportionately small compared to their relative biomass $(47$ to $52 \%$, also depending on what proportion of bacterial biomass was considered to be active). Estimates of respiration were much higher than measured rates of sediment oxygen consumption (2.5 to 5.5 times), although both followed closely similar seasonal trends. Bacterial production in nature must be directly measured before the validity of our calculations can be assessed. However, we conclude that it is possible to obtain reasonable estimates of annual production and its distribution among size groups in natural benthic communities of eukaryotic organisms using allometric P:B scaling.
\end{abstract}

\section{INTRODUCTION}

One of the goals of benthic ecology is to describe the pathways and quantities of energy and material flow in benthic communities over broad spatial and temporal scales. Benthic and pelagic components of aquatic ecosystems can be strongly coupled (Zeitzchel 1980), so models of marine ecosystems which attempt to quantitatively link energy flow between functional groups of pelagic and benthic organisms (e.g. Steele 1974. Mills \& Fournier 1979, Pomeroy 1979) often

\footnotetext{
- Present address: Newfoundland Environmental Consultants Limited, 36 Pippy Place, St. John's, Newfoundland A1B $3 \times 4$, Canada
}

encounter difficulties owing to inadequate information on broad-scale benthic consumption and production rates. The lack of data is particularly critical for small size organisms (bacteria, micro- and meiobenthos).

The partitioning of incoming food and subsequent respiration and production among benthic bacteria, micro- and meiofauna, and macrofauna has only been described for localized areas in a few studies (Fenchel 1967. Ankar 1979. Warwick et al. 1979, Dye 1981, Asmus 1982). In the first 3 of these studies, both production and respiration of various size groups of benthic organisms were measured or estimated. However, the time and labour involved in such efforts precludes the possibility of obtaining this information over large geographical areas. Usually only survey data which provide biomass estimates are available, 
although spatial studies of macrobenthic production (e.g. Wildish \& Peer 1983) and benthic community respiration (Smith \& Hinga 1983) have been carried out.

Numerous studies have examined allometric relations of metabolic rates and ecological characteristics with body size in natural populations and communities (Peters 1983, Calder 1984). Heip et al. (1984) have shown a relation between weight-specific annual production $(\mathrm{P}: \mathrm{B})$ and body size at maturity in laboratory and natural meiofaunal populations. Banse \& Mosher (1980) had earlier shown that such a relation exists over a very broad range of animal sizes, but that there is considerable scatter which may be associated with ecological and life-history characteristics of populations. Platt \& Denman (1978), following ideas presented by Sheldon et al. (1972) and Kerr (1974), showed that production in planktonic communities could be calculated from a model of the biomass spectrum by integrating the allometric function relating body size to production per unit biomass (P:B) over the size spectrum. Sheldon et al. (1977) used a similar approach to estimate fish production from measurements of phytoplankton biomass. In doing so, these authors indicated a possible method to provide regional surveys of benthic production by use of the size and ecological dependence of $\mathrm{P}: \mathrm{B}$ as demonstrated by Banse \& Mosher (1980) to estimate production by size classes of benthic organisms. Gerlach et al. (1985) have recently taken a slightly different approach and have integrated respiration per unit biomass over the size spectrum to calculate community respiration and partition it among meio- and macrofaunal size classes

If production estimates are not directed at particular species but at size classes of organisms, independent of species, then a useful generalization of the relations described by Banse \& Mosher (1980) results. This requires that their regressions of $\mathrm{P}: \mathrm{B}$ with body size at maturity be modified so that the body size parameter is the mean size of an individual in the population whose production is measured. We consider mean individual size as a time- and biomass-weighted average of all individual sizes measured over the period of measurement of production. The biases in estimating this statistic introduced by sampling and measurement errors (e.g. use of large mesh screens) are the same as those that affect production measurements. Therefore, some literature data which would have to be discarded if the Banse \& Mosher approach were used can be included in the data set to construct regressions for this generalized model. This approach also allows annual production to be estimated even for entirely immature populations (e.g. where some mortality factor reduces the population before maturity), for overmature populations, or for protists where the concept of maturity does not apply. It is also useful for communities where information on species composition or life histories is not available. In addition, since production and respiration are known to be logarithmically related over a broad size range of eukaryotic organisms (McNeil \& Lawton 1970, Banse 1979, Humphreys 1979) it should therefore be possible to approximate both community production and respiration. These calculations would allow total benthic energy demand over large areas to be determined from broad scale surveys of benthic community size structure.

A seasonal study of production dynamics of benthic organisms at an intertidal site in the upper reaches of the Bay of Fundy provided data from which production and respiration were calculated from measures of biomass in different organism size classes. We estimated annual production and respiration by bacteria, microalgae, micro- and meiofauna, and macrofauna using annual weighted means of approximately monthly observations of biomass in each group of organisms. Biomass data have been presented by Schwinghamer (1981b) and allometrically scaled P:B values are derived here from regressions calculated using published data for benthic organisms. We calculated respiration from production using relations between these variables rather than between respiration and biomass. The latter are derived solely from laboratory data and we felt that some of the inherent bias might be removed if production was first calculated from data on natural populations and then respiration calculated from this. We compared these estimates with synoptic field measurements of benthic community respiration and primary production (Hargrave et al. 1983) and with production and respiration of the 2 dominant macrofaunal species, Corophium volutator (Peer et al. 1980, Hawkins 1985) and Macoma balthica (Cranford et al. 1985).

\section{SITE DESCRIPTION}

Field measurement and samples were collected at an upper intertidal site about $50 \mathrm{~m}$ seaward of a fringing Spartina alterniflora marsh at Pecks Cove, New Brunswick, Canada (Fig. 1). Production of Macoma balthica was measured here and at 4 other nearby tidal flats (Cranford et al. 1985). The silt sediment has a median grain diameter of $15 \mu \mathrm{m}$ and a water content of $50 \%$ dry weight. The upper 5 to $10 \mathrm{~cm}$ of sediment is oxidized with redox potentials in excess of $+150 \mathrm{mV}$. There is no strongly developed sulfide layer at the Pecks Cove site, so anaerobic processes are not thought to be important. The site is flooded to a maximum depth of about $3 \mathrm{~m}$ for 3 to $4 \mathrm{~h}$ each semidiurnal tide. 


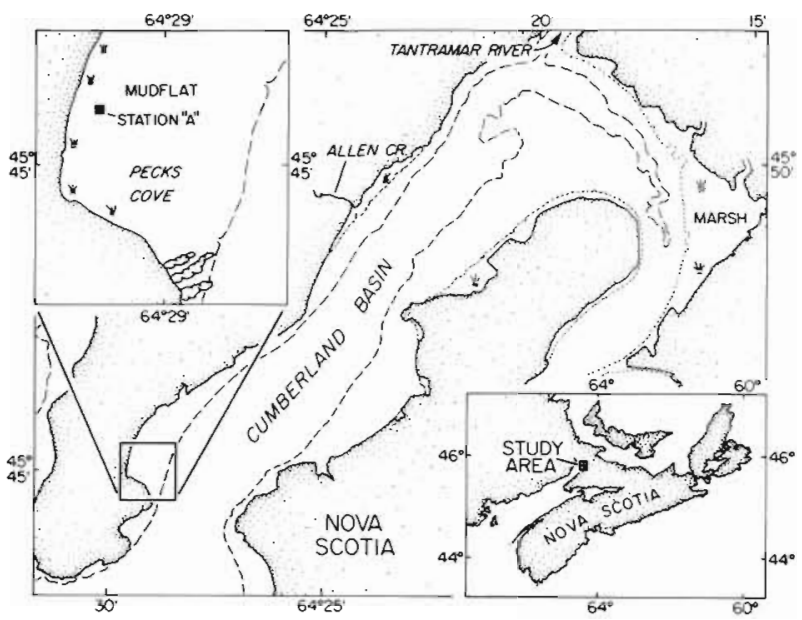

Fig. 1. Location of study site at Pecks Cove, New Brunswick, Canada

\section{METHODS}

Biomass determinations for bacteria, microalgae, micro- and meiofauna were made on replicate $5 \mathrm{~cm}^{2}$ cores taken to $10 \mathrm{~cm}$ sediment depth at approximately monthly intervals between March 1979 and March 1980. Macrofauna were collected to $15 \mathrm{~cm}$ depth in replicate $100 \mathrm{~cm}^{2}$ cores. Virtually all living biomass except some portion of the bacteria, whose biomass was still appreciable below $10 \mathrm{~cm}$, was included in core samples to this depth. Methods of extraction, sorting and size measurement for volume determinations are given by Schwinghamer (1981a, b, 1983).

To derive allometric scaling equations for calculating production from biomass, we gathered published data in which annual production had been estimated for various benthic populations and from which we could calculate the mean size of an individual in the population studied. Sources are listed in Table 1. Mean individual body size was calculated over the entire size range of the population and weighted according to the biomass distribution among size classes and over time, as well as for unevenly spaced sampling intervals. For short-lived populations which were absent or unmeasurably low in biomass over part of the year, mean size was calculated without weighting for those periods and total annual production was assumed to occur only during the period of measurable biomass. Benthic organisms inhabiting sediments (mostly marine) in temperate climates constituted the data set. No insects were considered. Most of the data were derived from natural species populations, however lack of such data in the smaller meiofaunal size range required us to consider some estimates derived from nematode cultures and also from mixed microbial populations whose species composition were not reported but whose mean individual size indicated protistan rather than bacterial populations (Meyer-Reil et al. 1980). In fact, we found no suitable data on annual production and biomass of natural bacterial populations in marine sediments. We have retained the use of the kilocalorie equivalent of body mass (Banse \& Mosher 1980) because conversion factors from wet or dry weight, if not given in the actual data, are available for most of the species, or at least for closely related species.

Ricker (1973) considered geometric mean (GM) regression as the method of choice to estimate, with minimum bias, functional bivariate relations in biological data whose variances are largely natural rather than due to measurement error. For mean individual body size this is certainly the case. It is also probable that inherent, natural variance owing to annual, specific, and population variations of measured P:B ratio at a given body size greatly exceeds measurement variance. GM regressions were calculated after logarithmic transformation of the variables. Because benthic biomass spectra consist of a mixture of 3 distributions, the bacteria, meiofauna (including microfauna), and macrofauna (Schwinghamer 1981a, 1983) and because the data of Banse \& Mosher (1980) give strong indication of an ecological dependence of $\mathrm{P}: \mathrm{B}$, we have calculated separate regressions for meiofauna (including microfauna) and macrofauna in addition to the overall regression (Fig. 2). The log-log regressions were transformed to the usual allometric power formulation (Fig. 2):

$$
\mathrm{P}: \mathrm{B}=\mathrm{a} \mathrm{W}^{\mathrm{b}}
$$

where body mass (W) is in kcal equivalents.

Production and respiration of benthic organisms at Pecks Cove were then calculated for $\log _{2}$ size classes ranging from bacteria through macrofauna using the appropriate scaling equation (Fig. 2, Table 2). Extrapolation from Equation $\mathrm{A}$ of Fig. 2 was used for bacteria since there were no literature data in the bacterial size range from which we could obtain a more suitable relation. Equation $B$ was used for macrofauna and Equation $C$ was used for both meiofauna and microalgae since microalgae were mainly in the meiofaunal size range and again, no other more suitable estimate was available. Then, for each sampling day, organisms were subdivided into $\log _{2}$ size classes, independent of species in the bacteria, microalgae, and meiofauna, and within each species of macrofauna using data from Schwinghamer (1981b). Annual mean biomass (weighted for sampling interval) in each size class was calculated and multiplied by the appropriate $\mathrm{P}: \mathrm{B}$ ratio to obtain annual production in that size class. Annual production by each of the 4 groups of organisms was calculated by summing production values for all size classes in each group (Table 3 ).

The effect of correcting for temperature on the esti- 
Table 1. Published data on production and biomass used in deriving allometric scaling equations (Fig. 2)

\begin{tabular}{|c|c|c|c|}
\hline Source & Taxon & $\begin{array}{l}\text { Body } \\
\text { mass }\end{array}$ & $\begin{array}{c}\text { Annual } \\
P: B\end{array}$ \\
\hline \multicolumn{4}{|l|}{ Meiofauna } \\
\hline Feller (1982) & Copepoda & $1.3 \times 10^{-5}$ & 3.7 \\
\hline Feller (1982) & Copepoda & $5.1 \times 10^{-6}$ & 3.9 \\
\hline Feller (1982) & Copepoda & $3.7 \times 10^{-6}$ & 3.2 \\
\hline Fleeger \& Palmer (1982) & Copepoda & $2.1 \times 10^{-6}$ & 18.0 \\
\hline Herman et al. (1983) & Ostracoda & $1.9 \times 10^{-5}$ & 2.6 \\
\hline Lasker et al. (1970) & Copepoda & $4.6 \times 10^{-6}$ & 2.5 \\
\hline Marchant \& Nicholas (1974) & Nematoda & $1.2 \times 10^{-6}$ & 19.0 \\
\hline Meyer-Reil et al. (1980) & 'Microbes' & $2.4 \times 10^{810}$ & 88.0 \\
\hline Scheimer et al. (1980) & Nematoda & $9.9 \times 10^{-8}$ & 6.8 \\
\hline Scheimer et al. (1980) & Nematoda & $2.1 \times 10^{-6}$ & 4.9 \\
\hline Smol et al. (1981) & Nematoda & $2.0 \times 10^{-5}$ & 4.7 \\
\hline \multicolumn{4}{|l|}{ Macrofauna } \\
\hline Birklund (1977) & Amphipoda & $1.4 \times 10^{-3}$ & 2.11 \\
\hline Buchanan \& Warwick (1974) & Polychaeta & $1.6 \times 10^{-2}$ & 1.31 \\
\hline Buchanan \& Warwick (1974) & Polychaeta & $5.0 \times 10^{-3}$ & 0.80 \\
\hline Buchanan \& Warwick (1974) & Polychaeta & $1.7 \times 10^{-3}$ & 0.80 \\
\hline Buchanan \& Warwick (1974) & Polychaeta & $1.4 \times 10^{-2}$ & 1.31 \\
\hline Buchanan \& Warwick (1974) & Polychaeta & $1.2 \times 10^{-2}$ & 0.87 \\
\hline Buchanan \& Warwick (1974) & Bivalvia & $4.0 \times 10^{-2}$ & 1.15 \\
\hline Cammen $(1980)$ & Polychaeta & $2.0 \times 10^{-3}$ & 2.0 \\
\hline Cederwall (1977) & Amphipoda & $1.9 \times 10^{-3}$ & 1.9 \\
\hline Cederwall (1977) & Amphipoda & $2.5 \times 10^{-3}$ & 1.4 \\
\hline Chambers \& Milne (1975a) & Polychaeta & $7.4 \times 10^{-3}$ & 4.52 \\
\hline Chambers \& Milne (1975b) & Bivalvia & $9.3 \times 10^{-3}$ & 1.79 \\
\hline Cranford (unpubl.) & Gastropoda & 0.19 & 2.1 \\
\hline Dame (1976) & Bivalvia & 0.79 & 2.0 \\
\hline Dixon (1976) & Bivalvia & $6.6 \times 10^{-3}$ & 1.8 \\
\hline Gratto et al. (1983) & Amphipoda & $3.1 \times 10^{-3}$ & 2.89 \\
\hline Hughes $(1970)$ & Bivalvia & 1.51 & 0.63 \\
\hline Johnson (1976) & Isopoda & 0.14 & 2.4 \\
\hline Klein et al. (1975) & Amphipoda & $1.1 \times 10^{-2}$ & 3.9 \\
\hline Kuenzler (1961) & Bivalvia & 2.8 & 0.91 \\
\hline Miller \& Mann (1973) & Echinoidea & 1.69 & 0.80 \\
\hline Mukai (1974) & Bivalvia & $1.5 \times 10^{-3}$ & 3.99 \\
\hline Mukai (1974) & Bivalvia & $2.3 \times 10^{-3}$ & 2.79 \\
\hline Mukai (1974) & Bivalvia & $3.1 \times 10^{-4}$ & 3.99 \\
\hline Mukai (1974) & Bivalvia & $6.7 \times 10^{-4}$ & 4.33 \\
\hline Nichols (1975) & Polychaeta & $2.3 \times 10^{-2}$ & 4.3 \\
\hline Peer $(1970)$ & Polychaeta & $1.8 \times 10^{-2}$ & 2.67 \\
\hline Rachor \& Salzwedel (1976) & Bivalvia & 0.50 & 1.5 \\
\hline Rachor \& Salzwedel (1976) & Bivalvia & 0.19 & 1.4 \\
\hline Richards \& Riley (1967) & Polychaeta & $4.8 \times 10^{-3}$ & 4.6 \\
\hline Richards \& Riley (1967) & Amphipoda & $3.3 \times 10^{-3}$ & 3.7 \\
\hline Sanders (1956) & Polychacta & $4.5 \times 10^{-3}$ & 2.7 \\
\hline Sanders (1956) & Polychaeta & $5.6 \times 10^{-3}$ & 1.9 \\
\hline Streit (1976) & Gastropoda & $2.2 \times 10^{-3}$ & 2.64 \\
\hline Streit (1976) & Gastropoda & $1.4 \times 10^{-3}$ & 5.94 \\
\hline Warwick \& Price (1979) & Bivalvia & $1.3 \times 10^{-2}$ & 3.5 \\
\hline Warwick \& Price (1979) & Bivalvia & $2.7 \times 10^{-3}$ & 4.8 \\
\hline Warwick \& Price (1979) & Bivalvia & 0.14 & 0.2 \\
\hline Warwick \& Price (1979) & Bivalvia & 0.10 & 0.9 \\
\hline Warwick \& Price (1979) & Polychaeta & $7.6 \times 10^{-2}$ & 1.9 \\
\hline Warwick \& Price (1979) & Polychaeta & $7.3 \times 10^{-3}$ & 5.1 \\
\hline Wildish (1984) & Amphipoda & $1.5 \times 10^{-3}$ & 2.0 \\
\hline Wildish (1984) & Amphipoda & $1.3 \times 10^{-3}$ & 1.4 \\
\hline
\end{tabular}




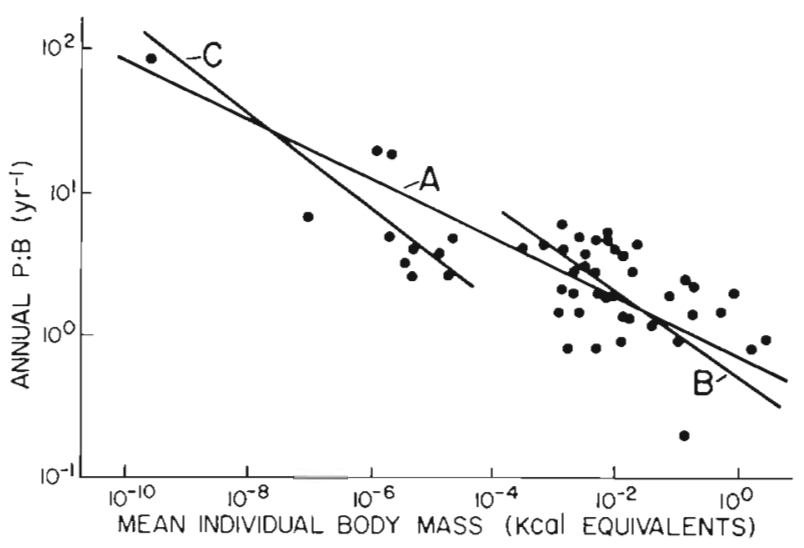

Fig. 2. Relations between annual $\mathrm{P}: \mathrm{B}$ and mean individual body mass (M), in kilocalorie equivalents, for benthic organisms. Lines are geometric mean functional regressions as described in 'Methods'. Regressions are as follows: $\mathrm{A}, \mathrm{P}: \mathrm{B}=$ $0.696 \mathrm{M}^{-0.208}, \mathrm{r}=-0.74 ; \mathrm{B}, \mathrm{P}: \mathrm{B}=0.525 \mathrm{M}^{-0.304}, \mathrm{I}=-0.50$

$$
\text { C, } \mathrm{P}: \mathrm{B}=0.073 \mathrm{M}^{-0.337}, \mathrm{r}=-0.83
$$

mates of production was assessed by making calculations for each size class on each day as if it were annual production. Values were then corrected for temperature changes throughout the year by using a $Q_{10}$ of 2 (Weiser \& Kanwisher 1961) and an average ice-free season temperature of $15^{\circ} \mathrm{C}$ and then divided by 365 to

Table 2. Annual P:B ratios and turnover times of sizes classes of benthic organisms estimated from regressions in Fig. 2. ESD = equivalent spherical diameter, $\mathrm{kcal}=$ approximate energy content of an organism of given ESD

\begin{tabular}{|c|c|c|c|}
\hline \multicolumn{2}{|c|}{ Organism size class } & \multirow{2}{*}{$\begin{array}{c}\text { Annual } \\
\text { P:B }\end{array}$} & \multirow{2}{*}{$\begin{array}{l}\text { Turnover } \\
\text { time }^{1} \text { (d) }\end{array}$} \\
\hline kcal & ESD & & \\
\hline \multicolumn{4}{|c|}{ Bacteria, Equation A } \\
\hline $8.18 \times 10^{-15}$ & $0.25 \mu \mathrm{m}$ & 593.0 & 0.6 \\
\hline $6.54 \times 10^{-14}$ & $0.5 \mu \mathrm{m}$ & 385.0 & 0.9 \\
\hline $5.24 \times 10^{-13}$ & $1.0 \mu \mathrm{m}$ & 249.0 & 1.5 \\
\hline $4.19 \times 10^{-12}$ & $2.0 \mu \mathrm{m}$ & 162.0 & 2.3 \\
\hline $3.35 \times 10^{-11}$ & $4.0 \mu \mathrm{m}$ & 105.0 & 3.5 \\
\hline \multicolumn{4}{|c|}{ Meiofauna and microalgae, Equation $\mathrm{C}$} \\
\hline $2.68 \times 10^{10}$ & $8.0 \mu \mathrm{m}$ & 123.0 & 3.0 \\
\hline $2.14 \times 10^{-9}$ & $16.0 \mu \mathrm{m}$ & 61.0 & 6.0 \\
\hline $1.72 \times 10^{-8}$ & $32.0 \mu \mathrm{m}$ & 30.0 & 12.0 \\
\hline $1.37 \times 10^{-7}$ & $64.0 \mu \mathrm{m}$ & 15.0 & 24.0 \\
\hline $1.02 \times 10^{-6}$ & $125.0 \mu \mathrm{m}$ & 7.6 & 48.0 \\
\hline $8.18 \times 10^{-6}$ & $250.0 \mu \mathrm{m}$ & 3.8 & 97.0 \\
\hline $6.54 \times 10^{-5}$ & $500.0 \mu \mathrm{m}$ & 1.9 & 194.0 \\
\hline \multicolumn{4}{|c|}{ Macrofauna, Equation B } \\
\hline $5.24 \times 10^{-4}$ & $1.0 \mathrm{~mm}$ & 5.2 & 70.0 \\
\hline $4.19 \times 10^{-3}$ & $2.0 \mathrm{~mm}$ & 2.8 & 132.0 \\
\hline $3.35 \times 10^{-2}$ & $4.0 \mathrm{~mm}$ & 1.5 & 248.0 \\
\hline 0.27 & $8.0 \mathrm{~mm}$ & 0.8 & 467.0 \\
\hline $1365 / \mathrm{P}: \mathrm{B}$ & & & \\
\hline
\end{tabular}

obtain a daily production rate (Table 3). Weighted sums of the daily rates were then calculated to give annual production incorporating a temperature correction for comparison with 'uncorrected' estimates in Table 3 .

Annual respiration ( $R$ ) of meiofauna and macrofauna was calculated from annual production (P) using a relation between $\mathrm{P}$ and $\mathrm{R}$ in benthic animals derived from data for benthic invertebrates in Banse (1979) and Banse \& Mosher (1980). The relation (in kcal m-2 $\mathrm{yr}^{-1}$ ) is:

$$
\log _{10} \mathrm{R}_{\mathrm{a}}=0.367+0.993 \log _{10} \mathrm{P}_{\mathrm{a}}
$$

It is independent of body size and is similar to those described by McNeil \& Lawton (1970) and Humphreys (1979) for non-insect invertebrates. Annual respiration was assumed to equal annual production in bacteria and microalgae. This assumption may not be far from correct (Humphreys 1979) but the ratio of $\mathrm{P}: \mathrm{R}$ varies greatly over the annual growth cycle in eukaryotes and is widely variable in sediment bacteria (van Es \& Meyer-Reil 1982). To compare estimated daily rates of respiration with measured sediment oxygen consumption, respiration values were calculated from temperature-corrected production for each day (before the latter was divided by 365) and then divided by 365 . Caloric values were converted to oxygen equivalents assuming that $1 \mathrm{mg} \mathrm{O}$ respired $=3.34$ calories $($ Parsons et al. 1984).

Methods for in situ measurement of benthic respiration and microalgal primary production in sediment cores exposed during low tide are given by Hargrave et al. (1983). Community respiration values cited here were calculated as the difference in total oxygen consumption between unpoisoned and formalin-poisoned, darkened cores. Water, enclosed over sediment in cores without air spaces, was not stirred during incubations. Stirring supernatant water during 5 experiments in August, September, and October, 1979 at Pecks Cove increased measured respiration rates by 2 to 11 times over rates determined in unstirred cores. The median increase (2.3) indicated that stirred cores would be expected to yield a respiration rate approximately twice that of unstirred cores. The relative magnitude of the difference, however, is directly related to the absolute rate of oxygen uptake so that the effect of stirring might be expected to be less during periods of low respiration and production (Hargrave unpubl. data). Oxygen production in sediment cores exposed to natural light during periods of low tide, corrected for total oxygen uptake, was used to measure gross primary production by benthic microalgae. Because of the method of calculation (Hargrave et al. 1983), the estimate of gross primary production was much less affected by stirring during experiments than was the respiration estimate. 
Table 3. Biomass and production of benthic organisms at Pecks Cove, Bay of Fundy. Daily production values are temperature corrected. Annual production is given both as temperature-corrected and uncorrected sum (weighted for sampling interval). Annual P:B values for each group are calculated from the uncorrected sum

\begin{tabular}{|c|c|c|c|c|}
\hline Date & Bacteria & Microalgae & Meiofauna & Macrofauna \\
\hline \multicolumn{5}{|c|}{ Biomass $\left(\mathrm{cm}^{3} \mathrm{~m}^{-2} \approx \mathrm{kcal} \mathrm{m}{ }^{-2}\right)$} \\
\hline \multicolumn{5}{|l|}{1979} \\
\hline 5 May & 63 & 3 & 3 & 33 \\
\hline $1 \mathrm{Jun}$ & 54 & 3 & 7 & 39 \\
\hline $3 \mathrm{Jul}$ & 58 & 36 & 30 & 8 \\
\hline 1 Aug & 55 & 46 & 11 & 9 \\
\hline 13 Sep & 60 & 126 & 22 & 4 \\
\hline 12 Oct & 48 & 43 & 15 & 19 \\
\hline $13 \mathrm{Nov}$ & 44 & 23 & 13 & 21 \\
\hline $12 \mathrm{Dec}$ & 48 & 6 & 14 & 6 \\
\hline \multicolumn{5}{|l|}{1980} \\
\hline $8 \mathrm{Feb}$ & 33 & 2 & 1 & $<0.1$ \\
\hline $20 \mathrm{Mar}$ & 52 & 1 & 11 & 13 \\
\hline Mean & 50 & 24 & 12 & 14 \\
\hline \multicolumn{5}{|c|}{ Production (kcal m $\left.\mathrm{m}^{-2} \mathrm{~d}^{-1}\right)$} \\
\hline \multicolumn{5}{|c|}{1979} \\
\hline 5 May & 44.0 & 0.15 & 0.06 & 0.10 \\
\hline 1 Jun & 43.0 & 0.17 & 0.12 & 0.13 \\
\hline $3 \mathrm{Jul}$ & 75.0 & 3.7 & 2.2 & 0.06 \\
\hline 1 Aug & 59.0 & 4.1 & 0.94 & 0.08 \\
\hline $13 \mathrm{Sep}$ & 102.0 & 18.0 & 1.3 & 0.08 \\
\hline 12 Oct & 32.0 & 1.8 & 0.39 & 0.12 \\
\hline 13 Nov & 22.0 & 0.85 & 0.20 & 0.10 \\
\hline $12 \mathrm{Dec}$ & 19.0 & 0.53 & 0.21 & 0.02 \\
\hline \multicolumn{5}{|l|}{1980} \\
\hline $8 \mathrm{Feb}$ & 8.7 & 0.01 & 0.01 & 0.0 \\
\hline $20 \mathrm{Mar}$ & 18.0 & 0.002 & 0.10 & 0.04 \\
\hline$P_{c o n}$ & 13624.0 & 808.0 & 171.0 & 25.0 \\
\hline $\mathrm{P}$ & 14745.0 & 573.0 & 147.0 & 29.0 \\
\hline Annual P: B & 292.0 & 24.3 & 12.5 & 2.0 \\
\hline
\end{tabular}

Methods for measurement of production and respiration by the amphipod Corophium volutator at Pecks Cove are given by Hawkins (1985) and Peer et al. (1980). Production values reported here are means of values from both studies calculated for dates on which observations of biomass were made. Annual production rates for the mollusc Macoma balthica at Pecks Cove and other nearby tidal flats were taken from Cranford et al. (1985).

\section{RESULTS AND DISCUSSION}

\section{Empirical relations between organism size and mass-scaled production}

A significant correlation $(r=-0.74, p<0.001)$ exists between log-transformed values of mean individual body size and annual $\mathrm{P}$ : $\mathrm{B}$ ratios in a broad size range of benthic organisms (Fig. 2). The exponent derived from GM regression of all of the data $(-0.208)$ is similar to the exponent of approximately -0.2 that Dickie \& Kerr (L. M. Dickie \& S. R. Kerr, Marine Ecology Laboratory, pers. comm.) derive from Banse \& Mosher's entire data set. Although this exponent does not differ significantly from -0.25 which would be characteristic if $\mathrm{P}: \mathrm{B}$ were strictly a physiological function (Calder 1984), it is significantly less negative than exponents $(-0.3$ to -0.4$)$ derived by Banse \& Mosher for non-insect invertebrates including benthic species. However, as suggested by Banse \& Mosher, the data in Fig. 2 can be divided into 2 ecological groups. The region around $10^{-5}$ to $10^{-3} \mathrm{kcal}$ body size corresponds to the size range of approximately $1 \mathrm{~mm}$ equivalent spherical diameter which separates meiofauna from macrofauna and is characterized by low biomass (Schwinghamer 1983, 1985) and species richness (Warwick 1984) in the size spectra of most benthic com- 
munities. When analyzed separately, the exponents derived for macrofauna $(-0.304)$ and meiofauna $(-0.337)$ are not significantly different from those calculated for ecological groupings of animals by Banse \& Mosher and others (Peters 1983, Calder 1984). Although the separate regressions yield similar exponents for macrofaunal and meiofaunal scaling equations, the difference between their coefficients (a) indicates that $P: B$ ratios of macrofauna are approximately 7 times what would be expected for organisms of this size if derived from the meiofaunal relation.

Within the range of body sizes used to derive the equations in Fig. $2\left(2.4 \times 10^{-10}\right.$ to $\left.2.8 \mathrm{kcal}\right)$, estimated $P: B$ ratios ranged from 0.8 to over $120 \mathrm{yr}^{-1}$ (Table 2). Bacterial P: B values, extrapolated from Equation $\mathrm{A}$ in Fig. 2 (105 to $590 \mathrm{yr}^{-1}$ ) were equivalent to turnover times of $14 \mathrm{~h}$ to $3.5 \mathrm{~d}$. This is within the lower end of the range of 0.3 to $20 \mathrm{~d}$ reported for sediment microbes by van Es \& Meyer-Reil (1982). Fallon et al. (1983) also found that FDC (frequency of dividing cells) estimates of bacterial turnover in sediments ranged from 16 to $60 \mathrm{~h}$ but that thymidine uptake experiments indicated much slower turnover rates, between 170 and $4400 \mathrm{~h}$. They argued that the thymidine uptake estimates were more reasonable in light of oxygen uptake measurements made on the same sediments. These latter rates would indicate $\mathrm{P}: \mathrm{B}$ ratios for sediment bacteria of only 2 to $52 \mathrm{yr}^{-1}$.

\section{Calculation of benthic production from biomass measurements and comparison with measured production}

Biomass and production contributed by each group of benthic organisms on each sampling day are given in Table 3 . The daily production values are temperature corrected as described in 'Methods'. The annual sums of production are given as both weighted sums of daily, temperature-corrected values and as simply calculated from $\mathrm{P}: \mathrm{B}$ and mean annual biomass, but $\mathrm{P}: \mathrm{B}$ values for each group are derived only from the latter. Although temperature correction has some influence on the magnitude of the estimate of annual production, its effect is not large and it does not alter the relative balances among the groups of organisms.

If all bacteria were metabolically active and if their $\mathrm{P}: \mathrm{B}$ were as high as the regression indicates, then regardless of the temperature correction, bacteria apparently contributed between 93 and $95 \%$ of annual total production in this community. This proportion did not fall below $84 \%$ of the total production on any of the sampling days. It is unlikely, however, that the entire bacterial population was always active or that the same proportion was active at all times throughout the year (Stevenson 1978). Our biomass estimates included all acridine-orange stained particles that resembled bacterial cells down to $10 \mathrm{~cm}$ sediment depth. Observations cited by van Es \& Meyer-Reil (1982), however, show that only between 1 and $10 \%$ of cells counted in sediments may be metabolically active. If an average annual P: B of 292 (Table 3) is applied to a mean active biomass of from 0.5 to $5 \mathrm{kcal} \mathrm{m}^{-2}$ (1 to $10 \%$ of the total), then annual bacterial production would be on the order of 150 to $1500 \mathrm{kcal} \mathrm{m}^{-2} \mathrm{yr}^{-1}$ rather than almost $15000 \mathrm{kcal}$ as estimated in Table 3. The lower estimates may be interpreted as indicating $P: B$ ratios of between about 3 and 30 for the total cell population. These are more in agreement with $\mathrm{P}: \mathrm{B}$ ratios calculated from thymidine uptake turnover times given by Fallon et al. (1983).

In Table 4 we compare our estimates of production with those of 2 other north temperate benthic studies. If we assume that $1 \%$ of the bacteria are active (i.e. $\mathrm{P}: \mathrm{B} \approx 3$ implied for the total biomass of bacteria), then annual production calculated for Pecks Cove is similar in magnitude to that determined for the other 2 sites. If we assume that $10 \%$ are active, then the $\mathrm{P}: \mathrm{B}$ implied for the total bacterial biomass $(\approx 30)$ would be more in agreement with the other studies, but our annual production would be much greater. On the other hand, the average $\mathrm{P}: \mathrm{B}$ ratios and the magnitude of annual production calculated for microalgae, meiofauna, and macrofauna at Pecks Cove are similar to those reported for the other sites. There is a particularly striking correspondence between production values estimated by Warwick et al. (1979) for the Lynher estuary and our estimates based on recast data from that study (in parentheses, Table 4). The relatively high P:B ratio for Pecks Cove macrofauna results from the small average size of the macrofauna at the study site where Corophium volutator and young Macoma balthica were dominant.

Measurements of gross primary production by benthic microalgae and secondary production by Corophium volutator and Macoma balthica at Pecks Cove and by $M$. balthica at 4 nearby tidal flats (Table 5) show that calculated and observed annual estimates are similar. Although errors in the estimates can be large relative to corresponding measured values (mean difference is $66 \%$ of the measured value), they are not large relative to the range of values that is possible even among different populations of one species. Individual differences between measured and estimated production average less than $25 \%$ of the range of values for $M$. balthica. Perhaps the extrapolation to estimate primary production by microalgae from a meiofaunal regression is tenuous but the estimate is reasonably good. Furthermore, data from Admiraal \& Peletier (1980) indicate a P : B ratio of 36 for 
Table 4. Average biomass $\left(B, \approx \mathrm{kcal} \mathrm{m}^{-2}\right)$ and annual production $\left(\mathrm{P}, \mathrm{kcal} \mathrm{m}^{-2} \mathrm{yr}^{-1}\right)$ for groups of benthic organisms in 3 coastal locations. Values for Pecks Cove and in parentheses for Lynher Estuary are calculated from regression equations in Fig. 2 as described in 'Methods'

\begin{tabular}{|c|c|c|c|c|}
\hline \multicolumn{2}{|l|}{ Organisms } & $\begin{array}{c}\begin{array}{c}\text { Baltic Sea' } \\
\text { Ásko }\end{array} \\
256\end{array}$ & $\begin{array}{c}\text { English Channel } \\
\text { Lynher Estuary }\end{array}$ & $\begin{array}{l}\text { Bay of Fundy } \\
\text { Pecks Cove } \\
\qquad 147-1474^{4}\end{array}$ \\
\hline Bacteria & $\begin{array}{l}\text { P } \\
\text { B } \\
P: B\end{array}$ & $\begin{array}{r}256 \\
10 \\
26\end{array}$ & $\begin{array}{c}34(152) \\
1 \\
34\end{array}$ & $\begin{array}{l}147-1474^{4} \\
0.5-5 \\
292\end{array}$ \\
\hline Microalgae & $\begin{array}{l}P \\
B \\
P: B\end{array}$ & - & $\begin{array}{l}1716(1707) \\
99 \\
17\end{array}$ & $\begin{array}{r}573 \\
24 \\
24\end{array}$ \\
\hline Meiofauna & $\begin{array}{l}P \\
B \\
P: B\end{array}$ & $\begin{array}{c}26 \\
6 \\
4.3\end{array}$ & $\begin{array}{l}245(223) \\
26 \\
9.4\end{array}$ & $\begin{array}{r}147 \\
12 \\
12\end{array}$ \\
\hline Macrofauna & $\begin{array}{l}P \\
B \\
P: B\end{array}$ & $\begin{array}{c}54 \\
46 \\
1.2\end{array}$ & $\begin{array}{l}66(66) \\
54 \\
1.2\end{array}$ & $\begin{array}{l}29 \\
14 \\
2.1\end{array}$ \\
\hline $\begin{array}{ll}1 & \text { Ankar (197 } \\
2 \text { Warwick et } \\
3 \text { Present stu } \\
4 \text { Metabolica }\end{array}$ & $\begin{array}{l}\text { 779) } \\
\text { ve bio }\end{array}$ & to be 1 to 1 & jiomass & \\
\hline
\end{tabular}

a population of benthic diatoms and our estimate for that population (mean cell size $=2.6 \times 10^{-8} \mathrm{kcal}$ ) would be 27 . For a first estimate of annual production by benthic eukaryotes, then, allometric scaling equations may be useful tools.

Table 5 also shows that the effects of different patterns of seasonal growth between species with differing life histories such as Corophium volutator and Macoma balthica are apparently smoothed out over an annual cycle and the 2 species follow a similar trend of

Table 5. Measured and calculated production rates (kcal $\mathrm{m}^{-2} \mathrm{yr}^{-1}$ ) for benthic microalgae and 2 dominant species of macrofauna at Pecks Cove. Production for macrofauna was calculated using Equation B (Fig. 2). Production by benthic microalgae was calculated from Equation C (Fig. 2) since their size range corresponded with the meiofaunal size range

\begin{tabular}{lcc}
\hline Organisms & Measured & Calculated \\
\hline Benthic microalgae $^{1}$ & 779 & 573 \\
Corophium volutator $^{2}$ & 38 & 30 \\
Macoma balthica & & \\
$\quad$ Pecks Cove & 1.1 & 3.1 \\
Horton Falts & 10.0 & 21.0 \\
Grande Anse & 22.0 & 39.0 \\
Daniels Flats & 25.0 & 30.0 \\
Elysian Fields & 38.0 & 30.0 \\
& & \\
1 Hargrave et al. (1983) assuming that $1 \mathrm{~g} \mathrm{C}=12 \mathrm{kcal}$ \\
${ }^{2}$ Hawkins (1985), Peer et al. (1980) \\
Cranford et al. (1985)
\end{tabular}

annual $P$ : $B$ on mean body size. The annual pattern of allocation of energy to production and respiration appears to take place within the context of general physiologically and ecologically determined allometric relations of these functions with body size. The overall exponent of -0.21 (Equation A, Fig. 2) does not differ significantly from a physiological relation with a -0.25 exponent according to the principles of dimensional analysis (Calder 1984). Superimposed on this and lying along the same overall trend are the relations within broad ecological groupings of organisms with characteristic exponents of -0.3 to -0.4 (Banse \& Mosher 1980 and present data). The evidence for this ecological scaling is as yet far from complete and requires more systematic data gathered to specifically test this model. Further reduction of the variance may result if a tertiary 'life history' scaling is added to this hierarchy of allometric relations, that is, if withinspecies scaling of $\mathrm{P}$ : B with body size over the life span of organisms is considered. Preliminary evidence indicates that the exponents which characterize the allometry of $\mathrm{P}: \mathrm{B}$ with size in species populations are, on average, more negative (on the order of -0.6 to $-0.7)$ but are also more variable than the 'higher level' ecological and physiological scaling exponents (Schwinghamer \& Peer unpubl. data).

\section{Partitioning of respiration in the benthic community}

Since estimates of annual production derived from mass-scaled P:B within ecological groups approxi- 
mated measured values at Pecks Cove, we compared benthic community respiration measured in undisturbed sediment cores with summed respiration calculated from temperature-corrected production estimates for the 4 groups of benthic organisms (Table 6). Because bacterial production estimates were only realistic if we assumed that between 1 and $10 \%$ of the population was active, we have used these estimates to calculate respiration as well. We have assumed that anaerobic metabolism was not significant at our sampling location but this assumption is based only on indirect evidence. In addition, the daily microalgal respiration rates in Table 6 do not reflect any variation in $P: R$ ratio over the growth cycle. This may seriously affect estimates of respiration especially during periods of high primary production such as in September 1979.

Total community respiration exceeded measured sediment oxygen uptake in 9 out of 10 cases when calculated as temperature-corrected daily respiration (Table 6). The annual daily average of oxygen uptake was only 20 to $40 \%$ of the annual average respiration estimated from production, depending on the percent of bacteria assumed to be active. Patterns of seasonal changes in estimated and measured respiration rates were similar $(r=0.90, p<0.001)$ but large discrepancies occurred, especially during periods of highest microalgal production when the measured community oxygen consumption may have seriously underestimated actual community respiration due to lack of water circulation in the cores. The large differences between observed and estimated respiration on these occasions may also reflect the effects of maximum seasonal sediment temperature and incident solar radiation on the $\mathrm{P}: \mathrm{R}$ ratio of the microalgae. Clearly, resolution of uncertainties in calculations of respiration by bacteria and microalgae and in measurement of community respiration is critical before rates of benthic respiration and production can be compared since the contribution by these 2 groups to total community metabolism is so great.

Respiration by Corophium volutator was measured on 5 of the sampling days and agreed overall with temperature-corrected estimates from Equation 2 ( $\mathrm{r}=$ 0.81). However, daily comparisons must be accepted with reservation as our estimates were derived from annual average values. More significantly, the average daily rates over the growth season calculated according to both methods were very close (estimated $\mathrm{R}=$ $21 \mathrm{mg} \mathrm{O}_{2} \mathrm{~m}^{-2}$, measured $\mathrm{R}=19 \mathrm{mg} \mathrm{O}_{2} \mathrm{~m}^{-2}$ ).

We do not consider it useful to compare the proportions contributed by each group to total community respiration on a month by month basis. The unknown fraction of bacterial biomass which was respiring aerobically and the unknown seasonal variability in $P: R$ in the microalgae prevent such comparisons, even using temperature-corrected values. However, even if as little as $1 \%$ of the bacteria were active, this small biomass contributed disproportionately to total annual respiration and production compared to the small contributions by meiofauna and macrofauna relative to their significant biomass (Table 7 ).

\section{Energy supply and demand in intertidal sediments at Pecks Cove}

Gross primary production by benthic microalgae at Pecks Cove was measured as $779 \mathrm{kcal} \mathrm{m}^{-2} \mathrm{yr}^{-1}$ and calculated from annual P:B and mean biomass values

Table 6. Respiration rates ( $\mathrm{mg} \mathrm{O} \mathrm{O}_{2} \mathrm{~m}^{-2} \mathrm{~d}^{-1}$ ) of groups of benthic organisms at Pecks Cove. Daily rates were calculated from temperature-corrected daily production rates as explained in 'Methods'. Mean annual rates were calculated from uncorrected annual production. $1 \mathrm{mg}$ oxygen respired was assumed to be equivalent to $3.34 \mathrm{cal}$

\begin{tabular}{|c|c|c|c|c|c|c|}
\hline Date & Bacteria & Microalgae & Meiofauna & Macrofauna & $\begin{array}{l}\text { Estimated total } \\
\text { (all groups) }\end{array}$ & $\begin{array}{l}\text { Measured benthic } \\
\text { respiration }\end{array}$ \\
\hline \multicolumn{7}{|l|}{1979} \\
\hline 5 May & $133-1330$ & 45 & 41 & 68 & $287-1484$ & 455 \\
\hline $1 \mathrm{Jun}$ & $129-1290$ & 51 & 81 & 88 & $349-1510$ & 127 \\
\hline $3 \mathrm{Jul}$ & $224-2240$ & 1105 & 782 & 41 & $2152-4168$ & 266 \\
\hline 1 Aug & $177-1770$ & 1234 & 629 & 54 & $2094-3687$ & 818 \\
\hline $13 \mathrm{Sep}$ & $306-3060$ & 5566 & 629 & 54 & $6801-9555$ & 1234 \\
\hline $12 \mathrm{Oct}$ & $95-950$ & 533 & 263 & 81 & $972-1827$ & 382 \\
\hline 13 Nov & $65-650$ & 254 & 135 & 68 & $522-1107$ & 310 \\
\hline $12 \mathrm{Dec}$ & $56-560$ & 159 & 142 & 14 & $371-875$ & 145 \\
\hline \multicolumn{7}{|l|}{1980} \\
\hline $8 \mathrm{Feb}$ & $26-260$ & 3 & 4 & 0 & $33-268$ & 0 \\
\hline $20 \mathrm{Mar}$ & $55-550$ & 1 & 68 & 27 & $151-646$ & 89 \\
\hline Annual mean & $121-1210$ & 470 & 271 & 54 & $916-2005$ & 366 \\
\hline
\end{tabular}


Table 7. Weighted annual mean biomass $\left(\mathrm{kcal} \mathrm{m}^{-2}\right)$, calculated annual production and respiration (kcal $\left.{ }^{-2} \mathrm{yr}{ }^{1}\right)$ of groups of organisms at Pecks Cove. Values are calculated on the basis of between 1 and $10 \%$ active bacterial biomass. Proportions contributed by each group are in parentheses

\begin{tabular}{|c|c|c|c|c|c|}
\hline & Bacteria & Microalgae & Meiofauna & Macrofauna & Total \\
\hline Biomass & $\begin{array}{c}0.05-5 \\
(0.001-0.09)\end{array}$ & $\begin{array}{c}24 \\
(0.44-0.48)\end{array}$ & $\begin{array}{c}12 \\
(0.22-0.24)\end{array}$ & $\begin{array}{c}14 \\
(0.25-0.28)\end{array}$ & $50-55$ \\
\hline Production & $\begin{array}{c}147-1474 \\
(0.16-0.66)\end{array}$ & $\begin{array}{c}573 \\
(0.26-0.64)\end{array}$ & $\begin{array}{c}147 \\
(0.07-0.16)\end{array}$ & $\begin{array}{c}29 \\
(0.01-0.03)\end{array}$ & $896-2223$ \\
\hline Respiration & $\begin{array}{c}147-1474 \\
(0.13-0.60)\end{array}$ & $\begin{array}{c}573 \\
(0.23-0.51)\end{array}$ & $\begin{array}{c}330 \\
(0.14-0.30)\end{array}$ & $\begin{array}{c}66 \\
(0.03-0.06)\end{array}$ & $1116-2443$ \\
\hline P: B & 292 & 24 & 12 & 2 & \\
\hline$R: B$ & 292 & 24 & 27 & 5 & \\
\hline
\end{tabular}

as $573 \mathrm{kcal} \mathrm{m}^{-2} \mathrm{yr}^{-1}$ (Table 3). Total aerobic respiration and production by heterotrophic organisms was estimated to be in the range 866 to $3520 \mathrm{kcal} \mathrm{m}^{-2} \mathrm{yr}^{-1}$ (Table 7) depending on the proportion of active bacteria. Even given the lower estimate, autochthonous primary production would be insufficient to support all of the heterotrophic requirements of the tidal flat community. A source of carbon in addition to microalgal production would be required. The most obvious source at Pecks Cove is the fringing Spartina alterniflora marsh which is less than $50 \mathrm{~m}$ away. Roberts (1982) found abundant fragments of Spartina as deep as $10 \mathrm{~cm}$ in the sediment at the same location. This material could be accumulated, refractory detritus deposited after more labile organic material has been lost by leaching and decomposition (Harrison \& Mann 1975). However, there was a decrease in bulk organic carbon in surficial sediment at Pecks Cove (from 1.5 to $0.3 \%$ dry weight) between September and November 1979 concurrent with decreases in community biomass and oxygen uptake as well as estimated production and respiration (Tables 3 \& 6). This implies rapid community response to changes in organic supply reflected in adjustments of biomass and metabolic activity. No estimate of anaerobic sulfate reduction by bacteria in these sediments is available, but if anaerobic conditions existed deeper in the scdiment or in association with buried detritus at shallower depths, the consumption rate of organic matter would be greater than that estimated from anaerobic respiration alone (Jørgensen 1977).

Respiration rates calculated from biomass and production using allometric equations were not directly comparable with sediment oxygen consumption measurements in unstirred cores because community respiration was probably underestimated by the latter. However, it appears that the proportional distribution of respiration between organism size groups and seasonal changes in rates reflect the dynamics of organic supply and consumption. Our data show that there is good agreement between measured and calculated rates of production by eukaryotic organisms but that serious problems in estimating and measuring in situ bacterial production remain.

\section{CONCLUSION}

Although it may be premature to state definitively that allometric relations of $\mathrm{P}: \mathrm{B}$ with body size and ecological factors may be used to estimate production of natural populations under most conditions, our data suggest that statements to the contrary would also be premature. The correspondence between measured and estimated production illustrated in Tables 4 and 5 is clearly more than fortuitous. It would be unwise to promote the uncritical use of this approach, or to suggest that it replace the more laborious methods of production measurement in all circumstances. Yet it is unfortunate that criticism of this approach may also result from lack of critical examination of the concepts involved, such as the difference between specific growth rates of individuals and annual $P: B$ ratios of populations (e.g. McLaren \& Corkett 1983). In addition, ecological groupings must be chosen carefully and, at the present stage, the choice may have to be solely an empirical one. We have separated meiofauna and macrofauna, not on the trophic and phyletic basis that Banse \& Mosher (1980) used, but rather because observations by Schwinghamer (1981a, 1983) and Warwick (1984) have indicated that they form 2 quite distinguishable communities. Yet the slopes (exponents, b) of the relation between $\mathrm{P}: \mathrm{B}$ and body size within each community were similar to those characteristic of the ecological groupings of Banse \& Mosher. For other purposes, other groupings may be preferable (e.g. Tremblay \& Roff 1983).

There are many studies of energetics of natural ani- 
mal and plant populations, yet our literature search indicated that only a small proportion of these contained the information required for calculations presented here. With applications such as we have presented and others (e.g. Tremblay \& Roff 1983, Gerlach et al. 1985) as background, it is desirable that a larger proportion of future studies of population energetics be designed to collect data suitable to a well-defined general paradigm of allometric relations in nature. The need for such an approach is particularly acute in the study of natural microbial populations.

Acknowledgements. We thank Mr. Tim Palmeter for his assistance in extracting data from published material

\section{LITERATURE CITED}

Admiraal, W., Peletier, H. (1980). Influence of seasonal variations of temperature and light on the growth rate of cultures and natural populations of intertidal diatoms. Mar. Ecol. Prog. Ser 2: 35-43

Ankar, S. (1979). Annual dynamics of a Northern Baltic bottom. In: Naylor, E. (ed.) Cyclic phenomena in marine plants and animals. Pergamon Press, Oxford, p. 29-36

Asmus, H. (1982). Field measurements on respiration and secondary production of a benthic community in the northern Wadden Sea. Neth. J. Sea Res. 16: 403-413

Banse, K. (1979). On weight dependence of net growth efficiency and specific respiration rates among field populations of invertebrates. Oecologia (Berl.) 38: 111-126

Banse, K., Mosher, S. (1980). Adult body mass and annual production/biomass relationships of field populations. Ecol. Monogr. 50: 355-379

Birklund, J. (1977). Biomass, growth and production of the amphipod Corophium insidiosum Crawford, and preliminary notes on Corophium volutator (Pallas). Ophelia 16: $187-203$

Buchanan, J. B., Warwick, R. M. (1974). An estimate of benthic macrofaunal production in the offshore mud of the Northumberland coast. J. mar. biol. Ass. U.K. 54: 197-222

Calder, W. A. (1984). Size, function, and life history. Harvard Univ. Press, Cambridge

Cammen, L. M. (1980). The significance of microbial carbon in the nutrition of the deposit feeding polychaete Nereis succinea. Mar. Biol 61: 9-20

Cederwall, H. (1977). Annual macrofauna production of a soft-bottom in the northern Baltic proper. In: Keegan, B. F., Ceidigh, P. O., Boaden, P. J. S. (ed.) Biology of benthic organisms. Pergamon Press, Oxford, p. 155-164

Chambers, M. R., Milne. H. (1975a). Life cycle and production of Nereis diversicolor O. F. Müller in the Ythan Estuary, Scotland. Estuar. coast. mar. Sci. 3: 133-144

Chambers, M. R., Milne, H. (1975b). The production of Macoma balthica (L.) in the Ythan Estuary. Estuar, coast. mar. Sci. 3: 443-455

Cranford, P. J., Peer, D. L., Gordon, D. C., Jr. (1985). Population dynamics and production of Macoma balthica in the Cumberland Basin and Shepady Bay, Bay of Fundy. Neth. J. Sea Res. 19: 135-146

Dame, R. F. (1976). Energy flow in an intertidal oyster population. Estuar. coast. mar. Sci. 4: 243-253

Dixon, D. R. (1976). The energetics of growth and reproduction in the brackish water serpulid Mercierella enigmatica
(Fauvel). In: Persoone, G., Jaspers, E. (ed.) Proc. 10th European Symp. Mar. Biol., Vol. 2. Universa Press, Wetteren, p. 197-209

Dye, A. H. (1981). A study of benthic oxygen consumption on exposed sandy beaches. Estuar. coast. Shelf Sci. 13: $671-680$

Es, F. B van, Meyer-Reil, L. -A. (1982). Biomass and metabolic activity of heterotrophic marine bacteria. Adv. microb. Ecol. 6: 111-170

Fallon, R. D., Newell, S. Y., Hopkinson, C. S. (1983). Bacterial production in marine sediments: will cell-specific measures agree with whole-system metabolism? Mar. Ecol. Prog. Ser. 11: 119-127

Feller, R. J. (1982). Empirical estimates of carbon production for a meiobenthic copepod. Can. J. Fish. Aquat. Sci. 39: 1435-1443

Fenchel, T. (1967). The ecology of marine microbenthos 1 : The quantitative importance of ciliates as compared with metazoans in various types of sediments. Ophelia 4: 121-137

Fleeger, J. W., Palmer, M. A. (1982). Secondary production of the estuarine meiobenthic copepod Microarthridion littorale. Mar. Ecol. Prog. Ser. 7: 157-162

Gerlach, S. A., Hahn, A. E., Schrage, M. (1985). Size spectra of benthic biomass and metabolism. Mar. Ecol. Prog. Ser. 26: 161-173

Gratto, G. W., Thomas, M. L. H., Bleakney, J. S. (1983). Growth and production of the intertidal amphipod Corophium volutator (Pallas) in the outer Bay of Fundy. Proc. Nova Scotian Inst. Sci. 33: 47-55

Hargrave, B. T., Prouse, N. J., Phillips, G. A., Neame, P. A. (1983). Primary production and respiration in pelagic and benthic communities at two intertidal sites in the upper Bay of Fundy. Can. J. Fish. Aquat. Sci. 40: 229-243

Harrison, P. G., Mann, K. H. (1975). Detritus formation from eelgrass Zostera marina L.: The relative effects of fragmentation, leaching and decay. Limnol. Oceanogr 20: 924-934

Hawkins, C. M. (1985). Population carbon budgets and the importance of the amphipod Corophium volutator in carbon transfer on Cumberland Basin mudflats, Bay of Fundy. Neth. J. Sea Res. 19: 165-176

Heip, C., Herman, P. M. J., Coomans, A. (1984). The productivity of marine meiobenthos. Academiae Analecta 44 (2): $1-20$

Herman, P. J. M., Heip, C., Vrancken, G. (1983). The production of Cyprideis torosa Jones 1850 (Crustacea, Ostracoda). Oecologia (Berl.) 58: 326-331

Hughes, R. N. (1970). An energy budget for a tidal-flat population of the bivalve Scrobiculana plana (Da Costa). J. Anim. Ecol. 39: 357-381

Humphreys, W. F. (1979). Production and respiration in animal populations. J. Anim. Ecol. 48: 427-453

Johnson, W. S. (1976). Population energetics of the intertidal isopod Cirolana harfordi. Mar. Biol. 36: 351-357

Jørgensen, B. B. (1977). The sulfur cycle of a coastal marine sediment (Limfjorden, Denmark). Limnol. Oceanogr. 22: 814-832

Kerr, S. R. (1974). Theory of size distribution in ecological communities. J. Fish. Res. Bd Can. 31: 1859-1862

Klein, G., Rachor, E., Gerlach, S. A. (1975). Dynamics and productivity of two population of the benthic tube-dwelling amphipod Ampelisca brevicornis (Costa) in Helgoland Bight. Ophelia 14: 139-159

Kuenzler, E. J. (1961). Structure and energy flow of a mussel population in a Georgia salt marsh. Limnol. Oceanogr. 6: 191-204 
Lasker, R., Wells, J. B. J., McIntyre, A. D. (1970). Growth, reproduction, respiration and carbon utilization of the sand-dwelling harpacticoid copepod Asellopsis intermedia. J. mar. biol. Ass. U.K. 50: 147-160

Marchant, R., Nicholas, W. L. (1974). An energy budget for the free-living nematode Pelodera (Rhabditidae). Oecologia (Berl.) 16: 237-252

McLaren, I. A., Corkett, C. J. (1983). Singular, mass-specific $\mathrm{P} / \mathrm{B}$ ratios cannot be used to estimate copepod production. Can. J. Fish. Aquat. Sci. 41: 828-830

McNeil, S., Lawton, J. H. (1970). Annual production and respiration in animal populations. Nature (Lond.) 225: $472-474$

Meyer-Reil, L.-A., Bolter, M., Dawson, R., Liebezeit, G., Szeverinskii, H., Walter, K. (1980). Interrelationships between microbiological and chemical parameters of sandy beach sediments, a summer aspect. Appl. environ. Microbiol. 39: 797-802

Miller, R. J., Mann, K. H. (1973). Ecological energetics of the seaweed zone in a marine bay on the Atlantic coast of Canada. III. Energy transformations by sea urchins. Mar. Biol. 18: 99-114

Mills, E. L., Fournier, R. O. (1979). Fish production and the marine ecosystems of the Scotian Shelf, Eastern Canada. Mar. Biol. 54: 101-108

Mukai, H. (1974). Ecological studies on distribution and production of some benthic animals in the coastal waters of Central Inland Sea of Japan. J. Sci. Hiroshima Univ. Serv. B, Div. 1 (Zool.) 25: 1-82

Nichols, F. H. (1975). Dynamics and energetics of three deposit-feeding benthic invertebrate populations in Puget Sound, Washington. Ecol. Monogr. 45; 57-82

Parsons, T. R., Maita, Y., Lalli, C. M. (1984). Manual of chemical and biological methods for seawater analysis. Pergamon Press, Oxford

Peer, D. L. (1970). Relation between biomass, productivity, and loss to predators in a population of a marine benthic polychaete, Pectinaria hyperborea. J. Fish. Res. Bd Can. 27: 2143-2153

Peer, D. L., Linkletter, L. E., Hicklin, P. W. (1980). Life history and production of Corophium volutator in the upper reaches of the Bay of Fundy. Tech. Rep. Can. Wildlife Service, Sackville, N.B., Canada

Peters, R. H. (1983). The ecological implications of body size. Cambridge Univ. Press, Cambridge, Mass.

Platt, T., Denman, K. (1978). The structure of pelagic marine ecosystems. Rapp. P.-v. Réun. Cons. int. Explor. Mer. 173: $60-65$

Pomeroy, A. J. (1979). Secondary production mechanisms of continental shelf communities. In: Livingstone, R. J. (ed.) Ecological processes in coastal and marine systems. Plenum Press, New York, p. 163-186

Rachor, E., Salzwedel, H. (1976). Studies on population dynamics and productivity of some bivalves in the Cerman Bight. In: Persoone, G., Jaspers, E. (ed.) Proc. 10th European Symp. Mar. Biol., Vol. 2. Universa Press, Wetteren, p. 575-588

Richards, S. W., Riley, G. A. (1967). The benthic epifauna of Long Island Sound. Bull. Bingham oceanogr Coll. 19: 89-135

Ricker, W E. (1973). Linear regressions in fishery research. J. Fish. Res. Bd Can. 30: 409-434

Roberts, D. L. (1982). Distribution of organic carbon and nitrogen in various natural particle types of a fine intertidal sediment. M.Sc. thesis, Dalhousie University

Sanders, H. L. (1956). Oceanography of Long Island Sound 1952-1954. X. The biology of marine bottom communities.
Bull. Bingham oceanogr Coll. 15: 345-414

Schiemer, F., Duncan, A., Klekowski, R. Z. (1980). A bioenergetic study of a benthic nematode, Plectus palustris de Man 1880, throughout its life cycle. Il. Growth, fecundity and energy budgets at different densities of bacteria food and general ecological considerations. Oecologia (Berl.) 44: 205-212

Schwinghamer, P. (1981a). Characteristic size distributions of integral benthic communities. Can. J. Fish. Aquat. Sci. 38: 1255-1263

Schwinghamer, P. (1981b). Size distributions of benthic organisms in the Bay of Fundy, Canada. Ph.D. thesis, Dalhousie University

Schwinghamer, P. (1983). Generating ecological hypothesis from biomass spectra using causal analysis: a benthic example. Mar. Ecol. Prog. Ser. 13: 151-166

Schwinghamer, P. (1985). Observations on size structure and pelagic coupling of some shelf and abyssal benthic communities. In: Gibbs, P. E. (ed.) Proc. 19th European Mar. Biol. Symp. Cambridge University Press, Cambridge, p. 347-359

Sheldon, R. W., Prakash, A., Sutcliffe, W. H., Jr. (1972). The size distribution of particles in the ocean. Limnol. Oceanogr. 17: 323-340

Sheldon, R. W., Sutcliffe, W. H., Jr., Paranjape, M. A. (1977). Structure of pelagic food chain and relationships between plankton and fish production. J. Fish. Res. Bd Can. 34: $2344-2353$

Smith, K. L., Jr., Hinga, K. R. (1983). Sediment community respiration in the deep sea. In: Rowe, G. T. (ed.) The sea. Vol. 8. Deep-sea biology. John Wiley and Sons, New York, p. $331-370$

Smol, N., Heip, C., Govaert, M. (1981). The life cycle of Oncholaimus oxyuris (Nematoda) in its habitat. Annls Soc. r. zool. malacol. Belg. 110: $87-103$

Steele, J. H. (1974). The structure of marine ecosystems. Harvard Univ. Press, Cambridge

Stevenson, L. H. (1978). A case for bacterial dormancy in aquatic systems. Microbial Ecol. 4: 127-133

Streit, B. (1976). Energy flow in four different field populations of Ancylus fluviatilis (Gastropoda-Basommatophora). Oecologia (Berl.) 22: 261-273

Tremblay, M. J., Roff, J. C. (1983). Production estimates for Scotian Shelf copepods based on mass specific P/B ratios. Can. J. Fish. Aquat. Sci. 40: 749-753

Warwick, R. M. (1984). Species-size distributions in marine benthic communities. Oecologia (Berl.) 61 32-41

Warwick, R. M., Price, R. (1979). Ecological and metabolic studies on free-living nematodes from an estuarine mudflat. Estuar. coast. mar. Sci. 9: 257-271

Warwick, R. M., Joint, I. R., Radford, P. J. (1979). Secondary production of the benthos in an estuarine environment. In: Jeffries, R. L., Davy, A. J. (ed.) Ecological processes in coastal environments. Blackwell, London, p. 429-450

Weiser, W., Kanwisher, J. (1961). Growth and metabolism in a marine nematode, Enoplus communis Bastian. Z. vergl. Physiol. 43: 29-36

Wildish, D. J. (1984). Secondary production of four sublittoral, soft-sediment amphipod populations in the Bay of Fundy. Can. J. Zool. 62: 1027-1033

Wildish, D. J., Peer, D. (1983). Tidal current speed and production of benthic macrofauna in the lower Bay of Fundy. Can. J. Fish. Aquat. Sci. 40 (Suppl. 1). 309-321

Zeitzchel, B. (1980). Sediment-water interactions in nutrient dynamics. In: Coull, B. C., Tenore, K. R. (ed.) Marine benthic dynamics. Univ. of South Carolina Press, Columbia, p. $195-218$ 